\title{
Who is more skilful? Doping and its implication on the validity, morality and significance of the sporting test
}

\author{
Ask Vest Christiansen ${ }^{\mathrm{a}, *}$, Rasmus Bysted Møller ${ }^{\mathrm{b}}$ \\ a Section for Sport Science, Department of Public Health, Aarhus University, Denmark \\ b Section for Sport Science, Department of Public Health, Aarhus University, Denmark Section for Sport Science, Department of Public Health, Aarhus \\ University, Dalgas Avenue 4, 8000 Aarhus C, Denmark
}

\section{A R T I C L E I N F O}

\section{Article history:}

Received 11 January 2016

Received in revised form 8 April 2016

Accepted 11 April 2016

Available online 1 June 2016

\begin{abstract}
A B S T R A C T
In this article, we explore if and in what ways doping can be regarded as a challenge to the validity, morality and significance of the sporting test. We start out by examining Kalevi Heinilä's analysis of the logic of elite sport, which shows how the 'spiral of competition' leads to the use of 'dubious means'. As a supplement to Heinilä, we revisit American sports historian John Hoberman's writings on sport and technology. Then we discuss what function equality and fairness have in sport and what separates legitimate form illegitimate ways of enhancing performance. We proceed by discussing the line of argumentation set forth by philosopher Torbjörn Tännsjö on how our admiration of sporting superiority based on natural talent or 'birth luck' is immoral. We analyse his argument in favour of eliminating the significance of meritless luck in sport by lifting the ban on doping and argue that its rationale is incompatible with the purpose of sport. We hereby show that although there certainly are morally problematic features of antidoping the idea that doping must be banned can be defended by reference to the constitutive function of physical differences in sport. In conclusion we show that although doping will never be eradicated from sport because of its ability to increase the physical differences that serve a constitutive function in sport, those differences are not primary in our fascination with elite sport. Instead, we argue for the sporting competition as a stage where fascinating narratives can unfold in a dramatized manner. The integrity of athletic excellence can thus survive even if doping continues to be a factor in sport.
\end{abstract}

(c) 2016 Elsevier Ltd. All rights reserved.

\section{Introduction}

When Finnish sport sociologist Kalevi Heinilä developed his theory of the Totalization Process of Sport in the 1970s he foresaw two of the major problems sport struggles with today. In his analysis Heinilä demonstrates 1) how international elite sport out of necessity develops into an enterprise involving all-encompassing systems surrounding the athlete(s) and 2) how athletes and elite sport systems eventually will be tempted to utilise 'dubious means' to enhance athletic performance. Those tendencies were evolving fast in a time of Cold War sports politics, when Heinilä wrote, but have only grown more evident in the decades that followed. Accordingly, doping has since the late 1990s been regarded as one of the biggest threats to the integrity of elite sport.

The aim of this article is to explore if and in which ways doping can be regarded as a challenge to the validity, morality and sig-

\footnotetext{
* Corresponding author.

E-mail address: avc@ph.au.dk (A.V. Christiansen).
}

nificance of the sporting test. We start out by examining Heinilä's more than 30 years old analysis of the logic of elite sport, which shows how the 'spiral of competition' leads to the use of 'dubious means'. As a supplement to Heinilä, we revisit the American sports historian John Hoberman's thoughts on sport and technology. Then we discuss what is understood by equality in sport and legitimate versus illegitimate ways of enhancing performance. This is followed by an analysis of what we believe to be the original foundation for our resistance to doping. We then discuss and criticise the line of argumentation set forth by Torbjörn Tännsjö on how our admiration of sporting superiority based on natural talent or 'birth luck' is immoral. We analyse the argument in favour of eliminating the significance of meritless luck in sport and argue that its rationale is incompatible with the purpose of sport. We hereby show that although there certainly are morally problematic features of anti-doping, the idea that doping must be banned can be defended by reference to the constitutive function of physical differences in sport. In conclusion, we show that although doping will never be eradicated from sport because of its ability to increase the phys- 
ical differences that serve a constitutive function of sport, those differences are not primary in our fascination with elite sport.

\section{A competition between systems}

Heinilä (1982) developed 25 theses to argue that sport logically develops into an arms race between nations competing for sporting excellence (Heinilä, 1982). He argues that because a victory in sport is inconclusive in nature (today's winner will be challenged tomorrow) a 'Spiral of Competition' is established. The logic is that: If you train $12 \mathrm{~h}$ per week, I will train 14 . If you do $14 \mathrm{~h}$, I will do 16 , and so forth. The 'Spiral of Competition' means that the demands for success in international sport are constantly upgraded leading to what Heinilä coined the 'Iron Law of Totalization'. With upgrading demands the athlete needs assistance regarding all issues affecting his or hers performance, i.e. training, diet, equipment, supplements, psychology, etc. Consequently, a system of support is established around the athlete.

The result is that in international sport, all other things being equal, better 'Systems' will outperform poorer systems: “As a consequence of continuous upgrading of demands in international sport, competition totalizes into a competition between 'Systems'" (Heinilä, 1982, thesis 8). Although it may appear that athletes just compete against each other as individuals or teams, success in toplevel sport is fundamentally dependent on the optimization of all background variables. The system of which the athlete or team is a representative must therefore - if it responds rationally and logically to the increasing international competition - optimize its performance capacity by adjusting all relevant parameters. For a system to be effective, it thus has to cover all kinds of relevant resources, which affect the outcome of competition, or "the productive capacity of the System", as Heinilä puts it. Since for the system the rule applies that " $\mathrm{t}]$ he more total the utilization of relevant resources, the greater the probability of international success" (Heinilä, 1982, thesis 10). Thus, totalization in the form of the development of a system of support is not restricted to a few elements but seeks to cover all resources that are considered relevant in elite sport. This condition is now a matter of course in all nations with Olympic ambitions-even in the United States, although the state here plays a limited role (Bosscher, 2008). Unsurprisingly, a system adopting the performance imperative increases the pressure on individual athletes and teams to succeed. And as Heinilä points out: "The greater the pressure to succeed the more likely the use of dubious means" (Heinilä, 1982, thesis 18).

Heinilä was not the only scholar in the 1980s to analyse the logic of elite sport in order to understand what was seen to be unwanted and unintended consequences of sport. Hoberman follows Heinilä as regards the spiral of competition and the resulting constant upgrading of demands in sport. The background for this, he adds, is that "sport is a global monoculture whose values derive in large measure from the sphere of technology" (Hoberman, 1988, p. 202-203). Following the French Philosopher Jacques Ellul, Hoberman views technology as efficient procedure per se. It is the logic of technique that calls for the mechanization of everything possible in order to obtain the highest possible level of efficiency. As for Heinilä's Iron Law of Totalisation, Ellul's technique aims for "efficient ordering", wherefore sport, Ellul argues, can be said to be "an extension of the technological spirit" (Hoberman, 1988, p. 207)). Sport is thus a particularly powerful symbol of the principle of unlimited performance by efficient procedures. This is for instance seen in how sport is highly influenced by a mechanical world-view that allows for bodily manipulation through scientific insights. Therefore, sport has come to exemplify how the performance of humans can be propelled forward by technology and science. Sport, according to Hoberman, thus represents an agenda for the development of the human body based on a technological machine-like image of man (Hoberman, 1988).

Viewed in this light doping in its various forms (from relatively simple injections of EPO (erythropoietin) and anabolic steroids over blood doping techniques to advanced gene modifications not yet in place) is a logical consequence of this mechanical anthropology. In line with Heinilä Hoberman fears the future development of elite sport and calls for ethical considerations that can lead to alternative future scenarios. However, because "our civilization provides us with very little in the cultural mainstream that can match the performance principle in mass appeal" Hoberman finds it "not particularly difficult" to predict how the debate will develop in the future. According to Hoberman "it is likely that a kind of athletic Nietzscheanism [...] will strain against certain prohibitions, primarily of religious origin, which prescribe that the human image should remain inviolate" (Hoberman, 1988, p. 204). As becomes clear later in our analysis of the pro-doping arguments, the debate on the ethics of doping and anti-doping developed in more diverse ways than Hoberman predicted.

Nevertheless, as we have clearly witnessed over the last 30 years, both Heinilä and Hoberman rightly predicted that doping is one of the 'dubious means' that has often been applied by athletes and teams to succeed in sport. Also, with Henilä's and Hoberman's perspectives on sport's embeddedness in a spiralling competition, and its fascination with technology, efficiency and rationality it is not a surprise that doping is not restricted to individual athletes, such as the terms 'doping sinner' or 'rotten apple', often used by journalists and officials, implicate. As revelations from top sport over the last 15-20 years has clearly demonstrated it is instead something that is known, and often organised, by the athlete's support system (Christiansen, 2005; Møller, 2010; Pound et al., 2015; Waddington and Smith, 2009). Hence, if we take the implications of Hoberman's and Henilä's analysis seriously (and there is no reason not to), rather than being a foreign element introduced by corrupt individuals, doping is best understood as an unintended consequence of the logic of elite sport and the technology-based performance principle that it incarnates.

Nevertheless, doping has been banned and fought because it is thought to spoil the integrity of athletic excellence. As many opponents of doping have argued; 'if the performances spectators witness are more a product of medical capabilities than athletic skills, what meaning does sport then have?' This line of thinking is also fundamental for the World Anti-Doping Agency (WADA) whose ambition it is to "protect the Athletes' fundamental right to participate in doping-free sport and thus promote health, fairness and equality for Athletes worldwide" (WADA, 2015, p. 11). Fairness and equality are thus presented as not only cornerstones in the global fight against doping but in sport per se. The tricky thing, however, is that fairness and equality are not universal values in sport but rather their application is restricted to very specific elements. The following examination shows that fairness and equality only serve instrumental purposes in elite sport.

\section{Sport and equality}

Sport, as the German philosopher Elk Franke has put it, is really an expression of inequality (Franke, 1987). The importance of fairness and equality lies in their ability to make sure that the right and proper kind of inequality is established. In order to substantiate this claim a closer look at the internal logic of sport is needed.

Sport is commonly understood as a test of primarily physical abilities (Kretchmar, 1998; Suits, 2007). Thus according to the sports philosopher Kathleen Pearson, the purpose of a sporting activity is: “... to test the skill of one individual, or group of individuals, against the skill of another individual, or group of 
individuals, in order to determine who is more skilful in a particular, well-defined activity، (Pearson, 1995, p. 183). In other words, sport enables us "to measure, compare and rank two or more competitors according to athletic performance', as sports philosopher Sigmund Loland puts it (Loland, 2002, p. 10). Rules serve both a constitutive and a regulatory function in sport and, and should, as sports philosopher John Russell states, 'be interpreted in such a manner that the excellences embodied in achieving the lusory goal of the game are not undermined but are maintained and fostered' (Russell, 1999, p. 35). Fairness and fair play are thus related to rule observance and to the importance of victory being representative of athletic superiority. In the words of James Keating: "Fairness or fair play, the pivotal virtue in athletics, emphasizes the need for an impartial and equal application of the rules, if the victory is to signify, as it should, athletic excellence" (Keating, 1978, p. 52). This means that if victory in a particular sporting competition is the result of an unequal application of the rules, it is not a true designator of superior athletic abilities in which case the competition has ceased to make sporting sense. Fairness and equality thus serve instrumental purposes as they stand for actions, attitudes and principles that help secure sport as a meaningful activity by safeguarding the symbolic value of victory as a mark of athletic superiority. The purpose of sport in this sense is ranking competitors according to athletic abilities and therefore Franke's view of sport as an expression of inequality, is on the mark.

This brings us back to Heinilä's description of today's elite sport systems and the inequality embedded in them. The idea of establishing expensive support systems around athletes in the first place, is exactly to utilise all possible resources in order to secure optimum performance. That is, to secure that our athlete or our team have advantages that your athlete or your team does not have. Indeed, everything an athlete does is done with the purpose of increasing performance and thus secure inequality or an un-level playing field. There thus seems to be in inbuilt paradox in the relationship between elite sport and anti-doping. Whereas the aim of athletes and teams is to create inequality, the WADA's raison d'être is to secure equality. Or rather: athletes want to increase inequality on all allowed parameters available for manipulation (training, diet, supplements, equipment, restitution, mental preparedness), whereas WADA seeks to control equality on one single parameter-namely doping. What doping is, however, is not evident since doping is only ostensibly defined as "as the occurrence of one or more of the antidoping rule violations set forth in Article 2.1 through Article 2.10 of the Code" (WADA, 2015, p. 18). These articles include (but are not limited to) the presence of a prohibited substance or its metabolites or markers in an athlete's sample; evading, refusing or failing to submit to sample collection; whereabouts failures and prohibited association with someone who is e.g. serving a period of ineligibility due to a doping offence. However, with sport characterised as an activity meant to determine "who is more skilful" where victory should "signify athletic excellence" and doping only ostensibly defined we are still left in need of a distinction between legitimate and illegitimate inequality. Which in turn raises the question of whether such distinction can be established in other than arbitrary ways.

\section{The validity of a sporting performance}

The deeper question in the above discussion is the question concerning validity. It can be phrased like this: "What exactly is it that makes a sporting performance valid?" What is, in other words, the validity test for a sporting performance vis-à-vis athletic excellence? The question of validity is crucial in science. It regards the relationship between the research question(s) asked, the method(s) applied and the result(s) obtained. To ask questions of validity is thus to ask whether we actually measure what we intend to measure. And the answers we give to this question have consequences for the trustworthiness of the results we present. Applied to our characterization of sport introduced above, this would in general terms mean that we should measure who is athletic superior in a given competition. But this is clearly too general. Hence, if transferred to a specific sporting competition the question of validity can be formulated as:

1) What is it we intend this competition to measure?

2) What does the competition actually measure?

Therefore, if we 1) want to find out who can ride a bike the fastest, we 2) need to set up a competition that can measure this. But for 1) to be realised we have to establish the relevant terms and conditions for that measurement, i.e. that competition, and then 2) find out whether the competition did in fact measure who was e.g. the fastest to ride a bike, i.e. who was athletic superior under the established conditions. The usual approach, following Keating's line of reasoning above, is to say that competition needs to take place on equal conditions. In turn, competition as a test of athletic superiority is valid if - and only if - it takes place on equal conditions. It is invalid if it does not take place on equal conditions. This is where most people usually put a full stop and cease further speculations. As mentioned above the challenge, however, is to establish what is to be understood by "equal conditions" in a sporting context. If it were only a question of having an impartial referee during the game, running on the same surface or having goals the same size things would be easy. However, we are also interested in how athletes obtained their level of fitness and this is where things start to become messy. What, again, distinguishes legitimate from illegitimate inequality?

As we have seen with Heinilä the athlete as an individual autonomous agent is not a practical reality in today's international elite sport culture. Elite athletes today are surrounded by sophisticated, expensive systems of support that help them enhance their performances. In much the same right as with doping, one could therefore ask: 'If the performances spectators witness are more a product of financial capabilities than athletic skills, what meaning does sport then have?' This is not just a rhetorical question. Even though sport officials in after dinner speeches like to emphasise how Olympic medals have to be won and cannot be bought, a study covering seven comparable nations on the effect of government funding of elite sport has shown otherwise: "In terms of input-output analysis, the best predictor of output appears to be the absolute amount of funding allocated to elite sport [...] more money in equals more medals out" (Bosscher, 2008, p. 134). Forty-five years ago when Avery Brundage was president of the International Olympic Committee, such direct influence of money on sport (the professionalization of sport) was judged to be intolerable. Thus, from this it appears that what constitutes a legitimate inequality changes over time: Once it was prohibited to buy the help of a trainer or other experts if an athlete wanted to compete in the Olympics - that is today perfectly acceptable. Once there were no sanctions associated with using performance enhancing drugs-that is today banned and heavily sanctioned. In short, whereas money was once thought to provide unequal conditions that would make the results of the sporting competition invalid, that is not the case today. The opposite is true for drugs.

To give an example that demonstrates the ambiguity of today's perspective on legitimate sporting aids, let us look at an aid that gives the athlete all of the following advantages:

- increases strength and power

- improves endurance 
- increases muscle oxygenation

- accelerates recovery processes

- removes lactic acid faster

- increases venous return

- reduces exercise induced muscle damage

- improves body temperature control

An artificial aid with those characteristics sounds like quite a potent drug and one may therefore be excused for thinking that it would banned from sport. But it is not. The reason for this is most likely that it is not a drug. It is a list of the advantages athletes are said to benefit from when they use clothing from the Australian company Skins-a company known for its vocal anti-doping stance (Skins, 2015). If the claims made by Skins are correct, access to such clothing gives athletes a significant advantage and places them in an unequal position to their competitors. If we (at least for the sake of the argument) accept Skins' claim that all these benefits are real, what then is it that makes an athletic performance accomplished with the help of Skins clothing (and an all-embracing system of support) more valid as an athletic performance than a performance done in old-fashioned cotton clothing but by an athlete who used some banned doping drug, for instance EPO? It is, as the former professional cyclist Joe Parkin stresses, always worth being "curious when the guy who brings a machine gun to a fistfight cries 'foul" (Parkin, 2008, p. 54). Framed in more general terms: Since all elite sport is about performance enhancement, we need a rationale for the distinction between legitimate and illegitimate performance enhancement that can help us answer the question on what it is that makes doping especially unacceptable as performance enhancing technique.

\section{Immoral doping}

The answer cannot be that doping is against the rules. As has been pointed out numerous times, the argument that doping is illegitimate because it is rule breaking, misses the point, since a change in the rules would dissolve this illegitimacy. Hence, to legitimize a rule with reference to the wrongness in violating the rule is a logical fallacy where the conclusion is presupposed in the premise. Furthermore, it cannot be because EPO is a performance enhancer and Skins clothing is not. That is not only demonstrated by Skins' own research, the list above, but is also evident from the performance principle's pivotal status in elite sport as shown in the above analysis by Heinilä and Hoberman respectively. In addition, the health argument against doping has been proven similarly unsound. Medically supervised drug use simply does not seem to have health implications that comes anywhere near the health risks athletes are exposed to by participating in sport (numerous scholars, see e.g. Houlihan, 2002; Møller, 2010). Hence, if we take our approach to answer such a question in WADA's two out of three criteria for considering something for the list of banned substances or methods we can rule out number 1 and 2 as single determinants. Under Section 4.3 of the World Anti-Doping Code, a substance or method is considered for inclusion on the prohibited list if WADA determines that the substance or method meets any two of the following three criteria: (1) that it has the potential to enhance or enhances sport performance; (2) that the use of the substance or method represents an actual or potential health risk to the athlete; and (3) WADA's determination that the use of the substance or method violates the spirit of sport (WADA, 2015). So, if no. 1 and 2 are ruled out, perhaps the answer lies in criteria no. 3; the spirit of sport. It is often argued that this is where the morality of anti-doping is embedded (McNamee, 2012).

Thus, our general resistance to doping and most people's initial judgment of Skins clothing being acceptable while doping is not acceptable, could be founded in doping being against the spirit of sport. On the basis of numerous surveys we think it is fair to claim that most people have a gut feeling that there is something inherently wrong with doping (e.g. Breivik, Hanstad, \& Loland, 2009; Hoberman, 2005, p. 226-227). And this is why we react stronger towards doping than to performance clothing or sophisticated support systems that may equally enhance the athlete's performance. If this is correct, we would also be able to say why the distinction between legitimate and illegitimate inequality is not simply arbitrary.

However, it has proven difficult to relate a gut feeling to a moral theory or one or more consistent moral arguments without having to sacrifice the enterprise of elite sport altogether (Christiansen \& Møller, 2007; Møller, 2012, 2010). Despite these difficulties, one should not neglect the intuitive resistance many people have regarding doping. Our hypothesis is that there is a rational foundation for this resistance but that it is not a moral one. Indeed, as argued by Belgian scholar Pieter Bonte, anti-doping makes fine sense in the light of evolutionary psychology. Bonte opens a commentary for the International Network for Doping Research (INDR) with this remark:

It makes deep evolutionary sense to be outraged by doping: nothing should impress a good beast more than signals of hereditary fitness - such as natural talent - and nothing is more infuriating (or at least off-putting) than being cuckolded into thinking that others are innately fit when actually they arenot. This may be why doping, like hair implants, meets with such ire and scorn. Doping is duping. Duping about innateness and heredity (Bonte, 2015).

According to this view, when we watch sport we want to see who is the fittest (in an evolutionary sense) and doping may conceal such observation. This perspective is also in line with that of Olympic founder Pierre de Coubertin who declared that the "characteristic of Modern Olympism is that it constitutes an aristocracy, an elite [...] determined purely by the physical superiority and muscular potentialities of the individual, enhanced to some degree by his will power and his training" (Coubertin, here quoted from Bonte, 2015). From an evolutionary psychological perspective, sport can thus be viewed as "culturally invented indicators of physical fitness." Therefore, if they should be valid as such indicators, sport officials naturally have to "disallow manifest attempts to compensate for a lack of birth luck. This means that you ban doping" (Bonte, 2015).

With Bonte's argument, that our resistance to doping is founded in psychological traits inherited through human evolution, and deep-rooted needs to be able to distinguish genetically superior individuals from genetically inferior individuals, an important understanding has been reached. We can now establish that the distinction we make between legitimate inequalities (such as national elite sport support systems and performance clothing) and illegitimate inequality (such as doping drugs) is not (completely) arbitrary. However, whereas the distinction makes fine evolutionary sense, it makes little moral sense. Thus, Bonte ends his commentary with the following passage:

The ban on emancipation from natural incapacitation may be justified from this atavistic, animalistic interest in discovering and glorifying those who have more talent, i.e. better genes. In itself this evolutionary psychological relic is a-moral and meaningless, but those who nevertheless enjoy to get these primal kicks can go ahead. To think such love of talent and hatred of doping is moral, however, makes no sense. To force this talentocratic a-morality on others, moreover, would be immoral (Bonte, 2015).

Bonte is not the only one who has pointed at the morally problematic nature of anti-doping as a way of securing the importance of naturalness in talent and performance. The Swedish Professor in practical philosophy, Torbjörn Tännsjö, has to our knowledge laid the foundation for this argument in his 1998 article: Is our 
Admiration for Sport Heroes Fascistoid? Here Tännsjö presents a critique of our tendency to admire winners on behalf of their natural talent and publicly displayed athletic strength. Tännsjö's critique was originally directed at spectators of sports but it has since been developed as an argument against anti-doping itself, latest in a keynote presentation at the 6th International 2015 INDR Conference in Aarhus, Denmark (Tännsjö, 2015). In light of Hoberman's analysis of the ethically problematic athletic Nietzscheanism involved in the technological enhancement of athletes, Tännsjö's arguments are interesting since he ends up suggesting that sport needs to promote exactly what Hoberman feared. At the same time Tännsjö's argument is the backdrop for Bonte's observations. Let us therefore take a closer look at this argument for allowing athletes to dope.

\section{Doping as a way to increase fairness in sport?}

Like Hoberman Tännsjö is also troubled by the fascist-like tendencies involved in the doping debate. But unlike Hoberman he finds those tendencies on the anti-doping side of the fence. ${ }^{1}$ Tännsjö draws inspiration from moral philosopher Harald Ofstad's book Our Contempt for Weakness in which Ofstad argues that the core of Nazism was not nationalism but contempt for weakness (Ofstad, 1998). Tännsjö uses this as a stepping stone to say that as we participate in the common celebration of winners we cannot help but feel contempt for those who do not win:

To see why this is so we ought to think critically about why we admire those who excel in the Olympics. Our feeling is based on a value judgment. Those who win the game, if the competition is fair, are excellent, and their excellence makes them valuable; that is why we admire them. Their excellence is, in an obvious manner, based on the strength they exhibited in the competition. And the strength they exhibit is "strength" in a very literal sense of the word. But our value terms are comparative. So if we see a person as especially valuable, because of his excellence [...] then this must mean that other people [...] those who are comparatively weak, are less valuable. The most natural feeling associated with this value judgement is-contempt (Tännsjö, 1998, p. 26-27).

Tännsjö is critical towards the fact that we are inclined to make a connection between moral worth and physical strength. He thus emphasises that "any person who feels that those who are in any sense 'strong' are better than those who are 'weak'-are open to the criticism that he or she has fallen prey to the core of Nazi ideology" (Tännsjö, 1998, p. 27). In general, Tännsjö argues, we "ought to resist the very idea of moral excellence and betterness", but particularly "the idea that moral excellence consists of strength", since such an idea borders on fascism (Tännsjö, 1998, p. 28). Allowing athletes to dope up to certain thresholds, Tännsjö further argues, eliminates, or at least drastically reduces, the significance of natural

\footnotetext{
${ }^{1}$ In the end of his article on sport and technology, Hoberman direct his readers' attention to the particularly close historical link between athleticism, the modernistic idealisation of the man-machine synthesis and Italian futurism. In the writings of the leading theorist of futurism Marinetti we can find exactly the kind of athletic Nietzcheanism Hoberman feared would come to dominate the doping debate because of the mass appeal of the performance principle. Although Hoberman does not directly mention the connection between Italian futurists and their dream of creating highly competitive super humans by bodily manipulation on the one side and fascist ideology on the other, the link is clearly there and has been elaborated by others (see for example Mangan, 1999). Hoberman's analysis can therefore be said to represent arguments in favour of anti-doping based on ethical considerations that acknowledge the importance of protecting the 'naturalness' of athletic talent and performance against a fascist-like athletic Nietzcheanism. Such an athletic Nietzcheanism endorse doping as a rational way towards the scientific creation of talents and performances-and in the end towards the creation of super-, or transhumans.
}

talent in which case equality between athletes is ideally increased promoting genuine fairness in sport.

It follows from this line of argument, that anyone with a genuine interest in equality should accept doping in order to create a level playing field where athletes can make up for their biological disadvantages, and even men and woman, can compete on an equal footing. If realized, Tännsjö argues, this ideal world of sport would value strength less and personal effort and cognitive abilities more, which, in turn, would create a less fascistoid and more humane sports world.

Tännsjö's equality-focused argument against anti-doping has a great deal of intuitive appeal. There does indeed seem to be something wrong with the idea of rewarding and glorifying persons who owe their success to pure birth-luck. Bonte therefore poses the right question when he asks: "Shouldn't we have to come up with a good reason that one man is allowed to have bio-capital and another is not?" (Bonte, 2015).

In order to answer Bonte's question, and subsequently determine whether we should then allow doping, as Tännsjö suggests, we need to take a look at the premise behind the equality-focused argument against anti-doping. The argument rests on the idea that sport, and the reward system that goes with it, will be more meaningful, fair and morally sound if athletes were allowed to be equal in all meritless aspects that may influence who will win. The argument focuses on our genetic makeup and especially that which gives rise to superior physical features-speed, power and endurance. However, genes only constitute part of what Bonte after Thomas Nagel calls constitutive luck. However, if we follow Nagel's idea we need to accept that there is more to constitutive luck than genes. According to Nagel constitutive moral luck concerns the personal character of an agent or simply who one is (Nagel, 2012). Genes are partly responsible but so are birthplace, upbringing, education and much more which are all largely, if not entirely, beyond one's control. So, if we take the notion of constitutive luck and Tännsjö's equality-focused argument seriously, we also ought to resist the tendency to judge athletes because of sportive character traits they were just lucky to have.

It is of course understandable that Tännsjö and other proponents of the equality-focused argument have chosen genetic makeup and physical capacity as the focus point of their critique. Efficient doping techniques are primarily directed at physical enhancement. But according to the logic of the equality-focused argument, more equality is always preferable to less with regard to meritless aspects of an athlete's constitution. Hence, if possible, not only physical but also cognitive differences should be levelled out. Let us imagine, as part of a reductio ad absurdum of the equality-focused argument, that this was possible. What would then happen? In the ideal case of perfect equality an absurd situation arises in which athletes in a race will arrive at the finish line at the exact same time. If someone reaches the finish line first, it would be the result of external factors outside the control of the athletes and the basis for any admiration would be gone. In fact, there would be no reason for sending them out of the starting blocks to begin with. We might as well announce the winner after a lottery or a draw from a deck of cards. In other words, if we take the logic of the equality-focused argument seriously and follow its logic and conclusions to the end, we end up in a situation where sport has been rendered meaningless. This is because inequality - especially physical inequality - is constitutive for sport. For sport to be meaningful, it is essential that victory ideally represents superior athletic abilities. And those abilities are largely attributable to physical differences. If we level out all the qualities that can make one athlete superior to another, we have removed the raison d'etre of sport. What for Bonte and Tännsjö appeared to be only a critique of anti-doping and the glorification of winners is fully thought through a radical critique of sport itself. 
Most likely, it will never be possible to even out all physical and mental differences between athletes, but that is beside the point. The point of our argument is simply that while the equality-focused argument in isolation might appear to be morally sound, the logic involved in its normative recommendations is incompatible with the purpose of sport. Thus, although the intention was to point to a morally brighter future for sport, it can in fact be unmasked as a radical critique that - if taken seriously - would mean the end of sport.

There is nothing wrong with being critical of sport. There are many good reasons to be so. But it is not reasonable to expect sports governing bodies to abandon anti-doping because of a rationale that is incompatible with the fundamental purpose and idea of sport. Sports governing bodies have the wellbeing of sport as their primary objective and it is hard to see how potentially making sport meaningless promotes this end. So, to answer Bonte's question in a slightly revised form: "why do we allow one athlete to have more mental- and bio-capital than another?" The answer is simple. Because these forms of inequality - especially physical inequality - are constitutive for sport.

While our preceding analysis shows that the fight against doping makes sense by protecting an element in sport that we find important, we cannot say the fight is moral. It may protect, however, the purpose of sport, if sport is to be understood as a contest "determined purely by the physical and mental superiority and muscular potentialities of the individual," as Bonte puts it. To be clear, our argument here is not meant as a comprehensive defence for antidoping in general, but a critique of equality-focused arguments in favour of lifting the ban. Where does this leave us regarding doping and our will to protect athletic excellence?

\section{Safeguarding athletic excellence}

First, with Heinilä and Hoberman we have to acknowledge that doping is inevitably associated with elite sport. That is, as long as we attach more meaning to winning than to loosing doping will be a temptation too big to be avoided by all athletes. In other words, doping can only be eradicated from international elite sport if we either a) reduce the importance of victory to a point where taking part is more important than winning, which would make use of performance enhancing drugs futile. Or b) submit all athletes to 24-7-365 surveillance, where every step they take is scrutinized, hence making concealed drug use impossible. Whereas the former idea would mean dissolving competition as the essence of sport and thus also make it largely uninteresting for (most) spectators, sponsors and possibly athletes, the latter involves a surveillance system that would approximate the realisation of George Orwell's 1984. Hence, we have to settle with less than an ideal world. We have to acknowledge that doping will always play a role in elite sport.

How do we then give meaning to the athletic excellence we witness at for instance the FIFA World Cup, The Olympic Games or the Tour de France? What doping does is that it enhances pure physical abilities. For instance, EPO increases oxygen delivery to the muscles, whereby endurance is enhanced, and anabolic steroids promote muscle growth thereby increasing strength and power. This means, as pointed out by sports philosopher Sigmund Loland, that the sports that are most vulnerable to doping are sports where the result is measured in centimetres, grams and seconds-the socalled CGS sport (Loland, 2004). The example par excellence of such a sport is the $100-\mathrm{m}$ dash. In this sport, pure physical skills are more important than any other kind of talent. Our fascination with this sport is thus tightly connected to the evolutionary psychological desire to see events with clear "indicators of physical fitness." However, despite this very few of us are fascinated by sport because of its ability to present to us who can produce the absolute amount of power or who can consume most litres of oxygen in a minute. Those are nerdy background variables for the performance, not the performance itself.

What fascinate most of us with elite sport is the drama, beauty, and narratives of the competitions. The drama that unfolds when rivals meet, the narrative of heroes and villains involved and the creativity, strategy, tactics, wit, courage, game reading and innovation players and athletes display as part of the competitions. None of these elements can be effectively enhanced by doping. Big football matches like those at the World Cup or between clubs like Real Madrid and Barcelona are sporting events packed with such characteristics. The same can be said of the Tour de France, with its 21 stages mirroring chapters in a book telling stories of intense rivalry and protagonists taking chances, and who are suffering, doubting, losing and winning. Obviously, the race also contained such drama when the disgraced cyclist Lance Armstrong dominated it. Our fascination with the race when he won seven years in a row cannot be retracted or regretted just because we now know that he doped (Møller, 2008). Also, his ability to read the race, place himself in the right positions, avoid crashes, think creatively, utilise the abilities of his team and play with tactics and controversies in other teams makes his performances fascinating, doping or not.

The point that our fascination with sport is not dependent on non-doped athletes may be even clearer if we contrast it with something complete void of the above description. If we instead of a cycle race in the geography of a landscape placed riders in a lab and simply measured who could produce the most watts per kilogram bodyweight over a given span of time we would have a CGS-discipline even more pure than the 100-m dash. If athletes were given free access to doping, such measurement would be almost entirely dependent on the athletes' inherited genetics and their ability to exploit the available drugs. But - this is our claim - it would not be very fascinating. Only few people would find it worth their while. In this way, sports competitions where the result is almost completely dependent on doping - where it is pure physiological performance that is measured - are also the least interesting. Or rather, to the extent that we do find them interesting it is, as Bonte points out, because of their ability to evoke in us a deep, evolutionary inherited desire to see who is the fittest.

\section{Conclusion}

Taking the point of departure in Heinilä's analysis of elite sport, we have shown in this article how it is unlikely that doping will ever be eradicated from sport. This is due to the 'Spiral of Competition', sport's entanglement with technology and drugs' ability to increase the physical differences that serve a constitutive function in sport. It is nevertheless difficult to point to legitimate versus illegitimate ways of enhancing performance in sport. This does not mean that we cannot explain our resistance to doping. We have argued that this resistance can be explained by psychological traits inherited through human evolution. There is, however, no moral ground for defending such atavistic need for being able to distinguish genetically superior individuals from genetically inferior ones. This observation has led to suggestions of lifting the ban on doping for ethical and equality-focused reasons. Yet, such equalityfocused argumentation leads to a collapse of the very purpose of elite sport, namely the measurement of physical differences. Based on this, there is a rationale for keeping the ban. Finally, we have shown that even though doping is very unlikely to be eradicated by upholding the ban on doping, our fascination with sport is not at risk of drying out, since the sporting competition is a stage where fascinating narratives can unfold in a dramatized manner. 
Sport is paradoxical. On the one hand, the spiral of competition, that is part of sport's inner logic, is the precondition for doping playing a role that may appear so dangerous that it could mean the end of sport. On the other hand, the logic of sport also contains the key to sport's own survival. Athletes' will to victory makes them go through displays of great drama that fascinates us much more than their underlying physiological and mental capabilities.

If we acknowledge that our fascination with elite sport is thus much more a fascination with aesthetics (the drama, beauty, and narratives of the competitions) rather than truth or science (the precise measurement of physical abilities), we can rest assured that athletic excellence will be safeguarded. This is because the question of validity is not as crucial in sport as it is in science. What is crucial, and the very nature of competitions, is the athletes' will to win and how that makes them go through various states of empathy, possession, sacrifice, obligation, victory and loss. What unfolds is a human drama that fascinates us. However, if we stick to the idea that only an ideal world eradicated of doping is good enough, then we will be left with a story of decay where we can only long back to an imaginary golden age before the Spiral of Competition made sport all too important.

\section{Acknowledgement}

The authors would like to thank the reviewers for their valuable comments to this paper.

\section{References}

Bonte, P. (2015). Anti-doping absolutism-a Darwinian demasqué. throwing some light on the (eugenic) dark side of anti-doping. INDR newsletter, (March 2015). [Retrieved from INHDR Newsletter website: http://ph.au.dk/en/about-the-department-of-public-health/sections/sectionfor-sport-science/research/research-unit-for-sports-and-physicalculture/international-network-of-doping-research/newsletters/march2015/inhdr-commentary-pieter-bonde/].

Bosscher, V. d. (2008). The global sporting arms race: an international comparative study on sports policy factors leading to international sporting success. Aachen: Meyer \& Meyer.

Breivik, G., Hanstad, D. V., \& Loland, S. (2009). Attitudes towards use of performance-enhancing substances and body modification techniques. A comparison between elite athletes and the general population. Sport in Society, 12(6), 737-754. http://dx.doi.org/10.1080/17430430902944183

Christiansen, A. V. (2005). The Legacy of Festina: patterns of drug use in European cycling since 1998. Sport in History, 25(3), 497-514.

Christiansen, A. V., \& Møller, V. (2007). Mål, medicin og moral: om eliteatleters opfattelse af sport, doping og fairplay (Ambitions, drugs and morality: On elite athletes' attitudes to sport, doping and fair play). Odense: Syddansk Universitetsforlag.
Franke, E. (1987). Ethische fragen im sport. In P. Schwenkmezger (Ed.), (pp. 40-65) Köln: Sportpsychologische Diagnostik, Intervention und Verantwortung.

Heinilä, K. (1982). The totalization process in international sport-toward a theory of the totalization of competition in top-level sport. Sportwissenschaft, 3 , 235-253.

Hoberman, J. M. (1988). Sport and the technological image of man. In W. J. Morgan, \& K. V. Meyer (Eds.), Philosophic inquiry in sport (2nd ed., pp. 319-327). Leeds, Campaign, IL: Human Kinetics.

Hoberman, J. M. (2005). Testosterone dreams: rejuvenation, aphrodisia, doping. Berkeley: University of California Press.

Houlihan, B. (2002). Dying to win: doping in sport and the development of anti-doping policy (2nd ed.). Strasbourgh: Council of Europe Publishing [fully revised edition].

Keating, J. (1978). Competition and playful activities. Washington: Rowman \& Littlefield.

Kretchmar, S. (1998). Soft metaphysics: a precursor to good sports ethics. In M. P. McNamee, \& Jim (Eds.), Ethics \&' sport. New York: Taylor and Francis.

Loland, S. (2002). Fair play. London: Routledge.

Loland, S. (2004). The vulnerability thesis and its consequences: a critique of specialization in Olympic sport. In J. Bale, \& M. K. Christensen (Eds.), Post-Olympism (pp. 189-199). Oxford, New York: Berg.

Møller, V. (2008). The doping devil copenhagen. Denmark: Books on Demand.

Møller, V. (2010). The ethics of doping and anti-doping: redeeming the soul of sport? London: Routledge.

Møller, R. B. (2012). Sport og Etik. En moralfilosofisk analyse af sporten (sport and ethics. A moral philisophical analysis of sport). (PhD). Aarhus: Aarhus University.

Mangan, J. (1999). Fascist body as political icon-global fascism. International Journal of the History of Sport, 16(4).

McNamee, M. J. (2012). The spirit of sport and the medicalisation of anti-doping: empirical and normative ethics. Asian Bioethics Review, 4(4), 374-392. http:// dx.doi.org/10.1353/asb.2012.0032

Nagel, T. (2012). Mortal questions. Cambridge University Press.

(1998). Our contempt for weakness. nazi norms and Values-and our own. Stockholm, Sweden: Almqvist and Wiksell.

Parkin, J. (2008). A dog in a hat: an American bike racer's story of mud, drugs, blood, betrayal, and beauty in Belgium. Boulder, Colorado: VeloPress.

Pearson, K. M. (1995). Deception, sportsmanship, and ethics. In K. V. William, J. Morgan, \& Meier (Eds.), Philosophical inquiry in sport. Human Kinetics Publishers.

Pound, R.W., McLaren, R.H., Robertson, J., Tinsley, D., Dubbey, M., Talay, B,.. Re, G., (2015). The independent commission report \#1 retrieved from Montral, Canada.

Russell, J. S. (1999). Are rules all an umpire has to work with? Journal of the Philosophy of Sport, 26(1), 27-49.

Skins. (2015). SKINS science-proofing instead of guessing. [Retrieved from http://www.skins.net/eu/skins-science].

Suits, B. (2007). The element of sport. In W. J. Morgan (Ed.), Ethics in sport. Human Kinetics Publishers.

Tännsjö, T. (1998). Is our admiration for sports heroes fascistoid? Journal of the Philosophy of Sport, 25(1), 23-34. http://dx.doi.org/10.1080/00948705.1998. 9714566

Tännsjö, T. (2015). Why the ban on doping is harmful paper presented at the evaluating the unintended effects of anti-doping. Aarhus, Denmark. http://ph.au. $\mathrm{dk} /$ fileadmin/ph/Idraet/INHDR/2015_Conference/Abstracts.pdf

Waddington, I., \& Smith, A. (2009). An introduction to drugs in sport: addicted to winning? (2nd ed.). Abingdon: Routledge.

World anti doping code 2015 (2015). 